Research article

\title{
THE INFLUENCE OF DIFFERENT CHEMICAL FORMS OF SELENIUM ADDED TO THE DIET INCLUDING CARNOSIC ACID, FISH OIL AND RAPESEED OIL ON THE FORMATION OF VOLATILE FATTY ACIDS AND METHANE IN THE RUMEN, AND FATTY ACID PROFILES IN THE RUMEN CONTENT AND MUSCLES OF LAMBS
}

\author{
MILTKO Renata, ROZBICKA-WIECZOREK J. Agnieszka, WIĘSYK Edyta, \\ CZAUDERNA Marian*
}

The Kielanowski Institute of Animal Physiology and Nutrition, Polish Academy of Sciences, Jabłonna, Poland

(Received 31 December 2015; Accepted 26 April 2016)

\begin{abstract}
Lambs were divided into 3 groups of 6 animals each. For 35 days lambs were fed a diet including $2 \%$ rapeseed oil, $1 \%$ fish oil and $0.1 \%$ carnosic acid (the control group) or two experimental diets supplemented with $0.35 \mathrm{mg} \cdot \mathrm{kg}^{-1} \mathrm{Se}$ as selenized-yeast $(\mathrm{SeY}$ ) (the $\mathrm{SeY}$ diet) or selenate (the selenate diet). Muscles (Musculus longissimus dorsi (MLD) and Musculus biceps femoris (MBF)), ruminal fluids and microbiota were collected from each lamb. SeY supplementation most effectively stimulated the accumulation of straightchain volatile fatty acids (VFAs), iso-branched-chain VFAs, $\mathrm{CO}_{2}$ and $\mathrm{CH}_{4}$ in the ruminal fluid. The contents of $\mathrm{CO}_{2}, \mathrm{CH}_{4}$ and VFAs including straight-chain VFAs with the exception of iso-branched-chain VFAs were most effectively reduced by the selenite diet. The control diet most efficiently increased the concentration sums of odd-saturated fatty acids (odd-SFAs) and iso-SFAs in microbiota. The SeY diet most efficiently reduced acetic acid to propionic acid ratio in the ruminal fluid. The selenate diet improved animal performance by reducing ruminal concentrations of $\mathrm{CH}_{4}$ and $\mathrm{CO}_{2}$. The SeY diet and especially the selenate diet reduced the biohydrogenation to C18:0 when compared with the control diet. The selenate diet more efficiently reduced the concentration sums of all SFAs ( $\Sigma \mathrm{SFAs}$ ) and all fatty acids ( $\Sigma \mathrm{FAs}$ ) in MLD and MBF than the SeY diet, which most effectively increased the concentrations of $\Sigma$ SFAs and $\Sigma F A$ s in $M L D$ and $M B F$. The selenate diet most effectively increased the body mass gain of lambs.
\end{abstract}

Key words: carnosic acid, fatty acids, methane, ovine rumen, seleno-compounds, volatile fatty acids

\section{INTRODUCTION}

The most common supplemental chemical forms of selenium (Se) for ruminants are selenite, selenate or selenized yeast $(\mathrm{SeY})$ [1,2]. The chemical form of Se affects

*Corresponding author: e-mail: m.czauderna@ifzz.pl 
biosynthesis yield of Se-complexes and Se-proteins in ruminal microorganisms [3]. Se-methionine (Se-Met) is more efficiently accumulated in the animal body than inorganic forms of Se. Organic chemical forms of Se undergo less alteration in the rumen leading to less of insoluble chemical forms of Se [1]. Ruminal micro-organisms are capable to metabolize organic and inorganic forms of Se into Se-amino acids (Se-AA). The poor bioaccumulation of inorganic Se has been linked to the ruminal environment whereby selenate or selenite is reduced by microorganisms to insoluble and unavailable elemental Se, which is excreted in the feces [1,3]; selenate has higher relative bioavailability value than selenite. Ruminal microorganisms can reduce excessive doses of organic or inorganic forms of Se to selenides or unabsorbable $\mathrm{Se}^{\mathrm{o}}$. Interestingly, Serra et al. [4] showed that dietary Se-compounds change the ruminal production of volatile fatty acids (VFAs). In fact, numerous studies showed that Secompounds affect ruminal microorganism yield and activity of microbiota [1-6]. Thus, Se-compounds affect VFAs production and rumen microbial fermentation $[5,6]$.

Analyses of the Se content in the ruminal microorganisms revealed that the microbial Se abundance was enriched relatively to the dietary level of Se [7]. Microorganisms are also able to synthesize Se-Met and Se-cysteine (Se-Cys), and these Se-AA are subsequently incorporated into microbial Se-proteins. Se-Cys is the essential component of antioxidant enzymes (like glutathione peroxidases) that decrease the risk of polyunsaturated fatty acids (PUFAs) peroxidation [8-11]. Numerous studies have established that phospholipid hydroperoxide glutathione peroxidase interferes more directly thus protecting PUFAs from peroxidation damage [8-12].

Interestingly, dietary carnosic acid (CA) modifies ruminal microbiota, the capacity of biohydrogenation or isomerisation and, hence, the ruminal biosynthesis of fatty acids (FAs) and VFAs, as well as the composition of FAs (especially PUFAs) in the ruminant body [13]. CA has a significant influence on the biosynthesis of volatile compounds in a dose dependent manner $[13,14]$. There is a lot of evidence that CA (polyphenolic compound) possesses antioxidative properties and hence protects from peroxidation damage the unsaturated fatty acids (UFAs), especially long-chain PUFAs (LPUFAs), in animal tissues [14]. Indeed, recent studies with CA have documented improvements in meat quality; CA seems to extend the shelf life of lamb meat [13].

Similarly to CA, dietary fish oil (FO) is able to modify the biohydrogenation yield by decreasing the enzymatic capacity for the isomerization of linoleic acid or a-linolenic acid, and simultaneously elevating trans11C18:1 (t11C18:1) level in ruminal contents and ruminant tissues $[15,16]$. FO, rich in LPUFAs, inhibited the growth (e.g., $B$. fibrisolvens) and activity of microorganisms (e.g., bacterial isomerase activity). PUFAs, especially LPUFAs, revealed toxic effects on cellulolytic bacteria and protozoa; PUFAs act against ruminal lactate producers thereby favouring propionate producers [16].

Therefore, we hypothesized that selenate or selenized yeast ( $\mathrm{SeY}$ ) added to the diet containing $\mathrm{CA}, \mathrm{FO}$ and $\mathrm{RO}$ would modify concentrations of VFAs, methane, $\mathrm{CO}_{2}$ and FAs in the rumen and contents of FAs in muscles. Moreover, we expected that these 
modifications depend upon the chemical form of dietary Se. Thus, the objective of our study was to investigate the impact of different chemical forms of $\mathrm{Se}$ (as $\mathrm{SeY}$ or selenate) added to the diet including $\mathrm{CA}, \mathrm{FO}$ and $\mathrm{RO}$ on the amounts of VFAs, FAs, methane and $\mathrm{CO}_{2}$ in the rumen and the concentrations of FAs (especially UFAs) in Musculus longissimus dorsi $(M L D)$ and Musculus biceps femoris $(M B F)$ of lambs.

\section{MATERIALS AND METHODS}

\section{Animals, diets, and experimental design}

Eighteen male Corriedale lambs with an average body weight (BW) of $30.4 \pm 2.6$ $\mathrm{kg}$ at the beginning of the experiment were individually penned and divided into 3 treatment groups of 6 animals (Tables 1 and 2). The animals were distributed into 3 groups, according to the initial mass of lambs; so that the average initial body mass of lambs between the groups were similar (Table 2). The study was conducted under the authority of the Third Local Commission of Animal Experiment Ethics at the University of Life Sciences, Ciszewskiego 8, 02-786 Warsaw, Poland (decision No 41/2013). During a 3-week preliminary period the animals were given free access to the standard concentrate-hay diet with vitamins and mineral premix ( Table 1). The basal diet $(\mathrm{BD})$ consists of the following components: meadow hay $(\sim 36 \%)$, a mixture of soybean meal $(\sim 36 \%)$ barley meal $(\sim 16.5 \%)$, wheat starch $(\sim 9 \%)$ and mineralvitamin mixture $(20 \mathrm{~g} / \mathrm{kg} \mathrm{BD})$. This basal diet contained: crude protein $120 \mathrm{~g}$, crude fibre $12 \mathrm{~g}$, and $11 \mathrm{MJ}$ metabolizable energy in $1 \mathrm{~kg}$ dry mater. The content of Se in 1 $\mathrm{kg}$ of the basal diet was $0.29 \mathrm{mg}$. The basal diet was supplemented with $2 \% \mathrm{RO}$ and $1 \%$ odourless fish oil (FO). After the preliminary period, for 35 days the lambs were fed the basal diet containing 2\% RO, 1\% FO and $0.1 \% \mathrm{CA}$ (the control diet) and two experimental diets (Table 2); these experimental diets were made by adding $0.35 \mathrm{mg}$ Se as SeY or selenate to $1 \mathrm{~kg}$ the control diet. The control and all experimental diets were formulated to be isoenergetic and isonitrogenous. All diets were adjusted weekly and supplied as two equal meals at 07.30 and 16.00 hours each day to ensure free access to the feed. Fresh drinking water was available at libitum. Animals completely consumed the served portion of the meals. All lambs were fed the same mass of freshly prepared diets with the appropriate additives (Table 2). The average daily diet intake was 1.08 $\mathrm{kg}$ per lamb. At the end of the 35-day experiment the lambs were slaughtered at 07.00 hour. Muscles (MLD and $M B F$ ) were removed, weighed, homogenized and frozen; all muscle samples were stored in sealed tubes at $-32^{\circ} \mathrm{C}$ until analysis. The whole digesta of the rumen were collected from each animal just after slaughter. Ruminal digesta samples were maintained at $39^{\circ} \mathrm{C}$ and ruminal fluid samples were obtained by straining through four layers of linen cloth $[15,17]$. The obtained ruminal digesta and fluid samples were frozen and stored in sealed tubes at $-20^{\circ} \mathrm{C}$ until analysed. Ruminal microorganism fractions were isolated from ruminal liquid by two-step centrifugation, according to Meyer et al. [18]. Obtained solid fraction samples were lyophilised. The 
fatty acid concentrations in ruminal microbiota were derived from the dry matter (DM).

Table 1. Chemical composition (\% in dry mass) of the concentrate-hay diet with vitamins and mineral mixture ${ }^{\mathrm{a}}$ (the basal diet), $\mathrm{RO}$ and $\mathrm{FO}^{\mathrm{b}}$

\begin{tabular}{|c|c|c|c|c|}
\hline \multirow{2}{*}{ Item } & \multirow{2}{*}{ Meadow hay ${ }^{d}$} & \multicolumn{3}{|c|}{ Concentrate $^{c}$} \\
\hline & & Barley meal & Soybean meal & Wheat starch \\
\hline Dry mass (\%) & 88.4 & 87.6 & 89.7 & 87.3 \\
\hline Crude protein $(\%)$ & 9.50 & 9.94 & 41.8 & 0.90 \\
\hline Crude fibre (\%) & 27.3 & 2.87 & 4.34 & - \\
\hline Crude fat $(\%)$ & 3.40 & 2.50 & 2.25 & 0.09 \\
\hline Ash (\%) & 4.85 & 1.84 & 6.16 & 0.12 \\
\hline Neutral detergent fiber $(\%)$ & 59.2 & 18.0 & 18.8 & - \\
\hline Acid detergent fiber (\%) & 32.1 & 4.61 & 6.44 & - \\
\hline Acid detergent lignin (\%) & 4.47 & 1.14 & 1.49 & - \\
\hline \multicolumn{5}{|c|}{ 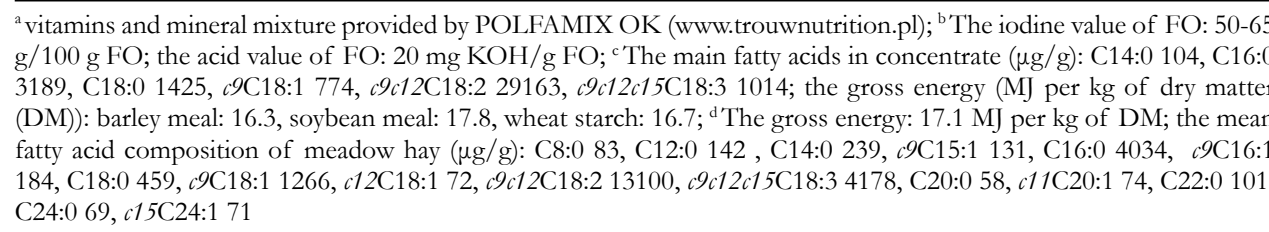 } \\
\hline
\end{tabular}

Table 2. The experimental scheme, the composition of the control and experimental diets, the body mass $(\mathrm{BM})$ of lambs and rumen content masses

\begin{tabular}{|c|c|c|c|c|c|}
\hline \multirow[b]{2}{*}{ Group $^{a}$} & \multirow[b]{2}{*}{$\begin{array}{l}\text { Additives added to } \\
\text { the basal diet }\end{array}$} & \multicolumn{2}{|c|}{ The body mass of lambs } & \multirow[b]{2}{*}{$\begin{array}{l}\text { Body mass } \\
\text { gain }^{\text {d }} \\
\%\end{array}$} & \multirow[b]{2}{*}{$\begin{array}{c}\text { Mass of } \\
\text { ruminal content } \\
\mathrm{kg}\end{array}$} \\
\hline & & $\underset{\substack{\text { initial } \\
\text { kg }}}{\mathrm{b}}$ & $\begin{array}{l}\mathrm{m}_{35 \text { days }} \mathrm{c} \\
\mathrm{kg}\end{array}$ & & \\
\hline Control & $\begin{array}{l}\text { The control diet: } \\
2 \% \mathrm{RO}, 1 \% \mathrm{FO} \text { and } 0.1 \% \mathrm{CA}\end{array}$ & $30.6 \pm 2.6$ & $37.2 \pm 2.3$ & $21.5 \pm 4.8$ & $4.34 \pm 0.51$ \\
\hline${ }^{\mathrm{SeY}} \mathrm{II}$ & $\begin{array}{c}\text { The SeY diet: } \\
2 \% \mathrm{RO}, 1 \% \mathrm{FO}, 0.1 \% \mathrm{CA} \\
\text { and } 0.35 \mathrm{mg} \mathrm{Se} \text { as } \mathrm{SeY} \\
\text { in } 1 \mathrm{~kg} \text { of the control diet }\end{array}$ & $\begin{array}{l}30.3 \pm 2.7 \\
(P=0.75)^{\mathrm{e}}\end{array}$ & $\begin{array}{l}36.8 \pm 2.7 \\
(P=0.99)\end{array}$ & $\begin{array}{l}21.6 \pm 3.2 \\
(P=0.47)\end{array}$ & $\begin{array}{l}4.15 \pm 0.60 \\
(P=0.47)\end{array}$ \\
\hline Selenate III & $\begin{array}{l}\text { The selenate diet: } \\
2 \% \mathrm{RO}, 1 \% \mathrm{FO}, 0.1 \% \mathrm{CA} \\
\text { and } 0.35 \mathrm{mg} \text { Se as selenate } \\
\text { in } 1 \mathrm{~kg} \text { of the control diet }\end{array}$ & $\begin{array}{l}30.3 \pm 3.0 \\
(P=0.52) \\
\left(P_{\mathrm{Se}}=0.96\right)^{\mathrm{f}}\end{array}$ & $\begin{array}{c}38.5 \pm 3.1 \\
(P=0.37) \\
\left(P_{\mathrm{Se}}=0.37\right)\end{array}$ & $\begin{array}{c}26.8 \pm 4.0 \\
(P=0.01) \\
\left(P_{\mathrm{Se}}=0.01\right)\end{array}$ & $\begin{array}{l}5.30 \pm 0.60 \\
(P=0.06) \\
\left(P_{\mathrm{Se}}=0.02\right)\end{array}$ \\
\hline
\end{tabular}

${ }^{\mathrm{a}}$ for the 3 -week of preliminary period lambs were fed the diet containing $2 \% \mathrm{RO}$ and $1 \% \mathrm{FO}$; ${ }^{\mathrm{b}}$ the average initial body mass of lambs after the 3 -week preliminary period; ${ }^{\mathrm{c}}$ the average body mass of lambs fed the diets for 35 days of the experimental period; ${ }^{\mathrm{d}}$ the relative body mass gain (BMG, \%) of lambs; BMG $(\%)=\left[\left(\mathrm{m}_{35 \text { days }}-\mathrm{m}_{\text {initial }}\right) \times 100 \%\right] / \mathrm{m}_{\text {initial }}$; ${ }^{\mathrm{e}}$ in parenthesis - statistical analyses of results; $P$-values: statistical analyses were carried out between the control group and the experimental groups ( ${ }^{\mathrm{SeY}} \mathrm{II}$ or $\left.{ }^{\text {Selenate }} \mathrm{III}\right) ;{ }^{\mathrm{f}} P_{\mathrm{Se}}-P$-values: statistical analyses were carried out between ${ }^{\mathrm{SeY}} \mathrm{II}$ group and Selenate III group 


\section{Chemicals}

Acetonitrile and n-hexane (99\%; GC) were purchased from Lab-Scan (Ireland). Volatile fatty acids (VFAs) and fatty acid standards, $25 \% \mathrm{BF}_{3}$ in methanol and sodium selenate were provided by Sigma-Aldrich (USA). All other chemicals were of analytical grade (POCh, Poland). Carnosic acid (CA) was purchased from Hunan Geneham Biomedical Technology Ltd. (Changsha Road, Changsha, Hunan, China). Rapeseed oil (RO) and fish oil (FO) were supplied by Company AGROSOL (Pacanów, Poland). RO comprised the following main fatty acids ( $\mu \mathrm{g} / \mathrm{g} \mathrm{RO}): \mathrm{C} 14: 0$ 56, C16:0 13091, c9C16:1 33, C18:0 5490, $9 \mathrm{C} 18: 1$ 385859, c12C18:1 786, c9c12C18:2 282394, c9c12c15C18:3 38474, C20:0 194, c11C20:1 108, C22:0 430 and c15C24:1 61. FO included the following main fatty acids ( $\mu \mathrm{g} / \mathrm{g})$ : C12:0 82, C14:0 12345, c9C14:1 215, C15:0 477, C16:0 56947,

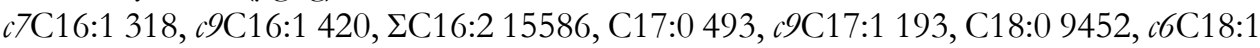
188, c7C18:1 842, c9C18:1 290592, c12C18:1 15834, c14C18:1 159, 9912C18:2 114512, c9c12c15C18:3 20968, c11C20:1 24206, c7c9c12c15C18:4 473, c11c14C20:2 2270, c8c11c14C20:3 258, c5c8c11c14C20:4 304, c8c11c14c17C20:4 607, C22:0 139, c13C22:1 11036, c11C22:1 1704, c5c8c11c14c17C20:5 6792, c13c16C22:2 95, c7c10c13c16C22:4 144, c15C24:1 397, c7c10c13c16c19C22:5 1560 and $c 4 c 7 c 10 c 13 c 16 c 19 \mathrm{C} 22: 626570$.

The vitamin and mineral mixture was purchased from POLFAMIX OK (Grodzisk Mazowiecki, Poland); $1 \mathrm{~kg}$ of vitamin and mineral mixture comprised: $285 \mathrm{~g}$ calcium, $16 \mathrm{~g}$ phosphorus, $56 \mathrm{~g}$ sodium, $42 \mathrm{mg}$ cobalt as carbonate, $10 \mathrm{mg}$ iodine as iodate, 1 $\mathrm{g}$ iron as sulphate, $6 \mathrm{mg}$ Se as selenite, $0.5 \mathrm{~g}$ copper as sulphate, $5.8 \mathrm{~g}$ manganese as sulphate, $7.5 \mathrm{~g}$ zinc as sulphate; vitamins: A (500 $000 \mathrm{IU} / \mathrm{kg}), \mathrm{D} 3(125000 \mathrm{IU} / \mathrm{kg})$, and $\mathrm{E}$ as $\alpha$-tocopherol (25000 IU/kg).

The selenized yeast (Se-Saccharomyces cerevisiae) was donated by Sel-Plex (Alltech In., USA); $\sim 83 \%$ of the Se content of the selenized yeast (SeY) represents Se in the form of Se-Met [19].

\section{Chromatographic equipment and analytical methods}

To $5 \mathrm{ml}$ of filtered ruminal fluid $0.5 \mathrm{ml}$ of $85 \%$ formic acid in water was added; it is recommended to store the resulting solution for $30 \mathrm{~min}$ at room temperature. The obtained solution was centrifuged at $15550 \mathrm{~g}$ for $30 \mathrm{~min}$ (at $4^{\circ} \mathrm{C}$ ). The supernatant in a sealed vial was stored at $4^{\circ} \mathrm{C}$ when not in use. Before gas chromatography, $75 \mu \mathrm{l}$ of the internal standard solution (1 $\mathrm{ml}$ of 4-methylvaleric acid in $100 \mathrm{ml}$ of water) were added to $0.5 \mathrm{ml}$ of the supernatant The analyses of VFA were performed on a gas chromatograph (GC-2010 SHIMADZU) equipped with a Zebron ${ }^{\text {TM }}$ ZB-FFAP column $(30 \mathrm{~m}$ x $0.25 \mathrm{~mm}$ i.d. x $0.25 \mu \mathrm{m}$ film thickness; the phase: nitroterephthalic acid modified polyethylene glycol; Phenomenex) and a flame ionization detector (FID). Helium as the carrier gas operated at the initial pressure $(37.3 \mathrm{kPa})$ and the constant column flow rate of $0.87 \mathrm{ml} / \mathrm{min}$. The injector and FID temperatures were maintained at 250 and $280^{\circ} \mathrm{C}$, respectively. $\mathrm{H}_{2}$ and air flows were 40 and $400 \mathrm{ml} / \mathrm{min}$. The injector and FID temperatures were maintained at 200 and $240^{\circ} \mathrm{C}$, respectively. 
The VFAs profile in $1 \mu \mathrm{l}$ sample at a split ratio of 10:1 was determined using the column temperature gradient programme. The oven temperature was programmed as follows: initially $80^{\circ} \mathrm{C}$ for $1 \mathrm{~min}$, increasing by $15^{\circ} \mathrm{C} / \mathrm{min}$ to $220^{\circ} \mathrm{C}$, held for $4 \mathrm{~min}$; the total run time of the GC-FID analysis was $15 \mathrm{~min}$.

Methylations were introduced for preparation of methyl esters of fatty acids (FAMEs) in ruminal fluid, microbiota and muscle samples [20]. FAMEs were then quantified using gas-chromatography according to Rozbicka-Wieczorek et al. [20]. The analyses of FAMEs were performed on a SHIMADZU GC-MS-QP2010 Plus EI equipped with a BPX70 fused silica column $(120 \mathrm{~m} \times 0.25 \mathrm{~mm}$ i.d. $\times 0.25 \mu \mathrm{m}$ film thickness; SHIM-POL and a quadrupole mass selective detector (Model 5973N).

\section{Calculation of the concentrations of $\mathrm{CO}_{2}$ and $\mathrm{CH}_{4}$ in the rumen}

Contents of $\mathrm{CO}_{2}$ and $\mathrm{CH}_{4}$ in the rumen were calculated according to Wolin [21].

\section{Statistical analysis}

Statistical analysis was performed using the Statistica software package (StatSoft, Version 10, 2010). Statistical analyses of dietary effects of SeY or selenate added to the diet including FO, RO and CA on concentrations of VFAs and FAs in ruminal samples and concentrations of FAs in $M L D$ and $M B F$ of lambs were conducted using the non-parametric Mann-Whitney $U$ test. Differences were considered significant at $\mathrm{P}<0.05$ or $\mathrm{P}<0.01$, while at $\mathrm{P}<0.10$ differences were taken as tendencies. The results are presented as the means of the individually analyzed ruminal and muscle samples $(n=6)$. The results are presented as the meantthe standard deviation.

\section{RESULTS}

Neither macroscopic lesions nor pathological changes were found in the muscles and in any other internal organ of lambs fed the control, SeY or selenate diets. The selenate diet more efficiently increased $(\mathrm{P}=0.01)$ the body mass gain $(\mathrm{BMG})$ of lambs than the control and SeY diets (Table 2). This diet increased also the ruminal content mass when compared with the control $(\mathrm{P}<0.1)$ and SeY $(\mathrm{P}<0.05)$ diets. In contrast, the $\mathrm{SeY}$ diet revealed negligible impact on the BMG and the ruminal content mass in comparison with the control diet.

\section{Effects of diets on concentrations of VFAs, methane and $\mathrm{CO}_{2}$ in the ruminal fluid}

The SeY diet increased the concentration sums of all VFAs ( 2 VFAs) in the ruminal fluid when compared with the control $(\mathrm{P}<0.05)$ and selenate $(\mathrm{P}<0.01)$ diets (Table 3). Consequently, the SeY diet more effectively stimulated the accumulation of all straight-chain VFAs $(\mathrm{P}<0.05$ or $\mathrm{P}<0.1)$ than the control and selenate diets. The SeY 
diet increased $(\mathrm{P}<0.05)$ the concentrations of iso-VFAs $(i-\mathrm{BA}$ and $i$-VA) in the fluid when compared with the control diet. The SeY diet resulted in a insignificant increase $(\mathrm{P} \geq 0.3)$ in the $i$-BA and $i$-VA contents in the fluid in in comparison with the selenate diet.

Table 3. The concentrations ${ }^{a}$ of volatile fatty acids (VFAs), the sum of VFAs and the ratio of AA to PA (AA/PA) in the ruminal fluids

\begin{tabular}{|c|c|c|c|c|c|c|c|c|c|}
\hline Group & & $\begin{array}{l}\text { Acetic } \\
\text { Acid } \\
\text { (AA) }\end{array}$ & $\begin{array}{c}\text { Propionic } \\
\text { acid } \\
\text { (PA) }\end{array}$ & $\begin{array}{c}\text { iso- } \\
\text { Butyric } \\
\text { acid } \\
\text { (i-BA) }\end{array}$ & $\begin{array}{c}\text { Butyric } \\
\text { acid } \\
\text { (BA) }\end{array}$ & $\begin{array}{c}\text { iso-Valeric } \\
\text { acid } \\
\text { (i-VA) }\end{array}$ & $\begin{array}{c}\text { Valeric } \\
\text { acid } \\
\text { (VA) }\end{array}$ & 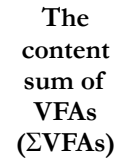 & $\begin{array}{l}\text { Ratio of } \\
\text { AA to PA } \\
\text { (AA/PA) }\end{array}$ \\
\hline Control & $\begin{array}{c}\mathrm{mM} / 100 \mathrm{ml} \\
\%\end{array}$ & $\begin{array}{c}3.8 \pm 0.3 \\
64.1\end{array}$ & $\begin{array}{c}1.1 \pm 0.3 \\
18.5\end{array}$ & $\begin{array}{c}0.14 \pm 0.03 \\
2.38\end{array}$ & $\begin{array}{c}0.65 \pm 0.11 \\
10.8\end{array}$ & $\begin{array}{c}0.18 \pm 0.05 \\
3.05\end{array}$ & $\begin{array}{c}0.073 \pm 0.026 \\
1.20\end{array}$ & $\begin{array}{c}6.0 \pm 0.7 \\
100\end{array}$ & $\begin{array}{c}3.5 \pm 0.5 \\
3.46\end{array}$ \\
\hline${ }^{\mathrm{SeY}} \mathrm{II}$ & $\begin{array}{c}\mathrm{mM} / 100 \mathrm{ml} \\
\%\end{array}$ & $\begin{array}{c}4.6 \pm 0.6 \\
\mathrm{~m}(P=0.02)^{\mathrm{b}} \\
62.4\end{array}$ & $\begin{array}{c}1.5 \pm 0.4 \\
(P=0.03) \\
19.8\end{array}$ & $\begin{array}{c}0.18 \pm 0.04 \\
(P=0.048) \\
2.41\end{array}$ & $\begin{array}{c}0.79 \pm 0.18 \\
(P=0.08) \\
10.5\end{array}$ & $\begin{array}{c}0.27 \pm 0.09 \\
(P=0.046) \\
3.58\end{array}$ & $\begin{array}{c}0.107 \pm 0.036 \\
(P=0.082) \\
1.39\end{array}$ & $\begin{array}{c}7.5 \pm 1.3 \\
(P=0.02) \\
100\end{array}$ & $\begin{array}{c}3.1 \pm 0.4 \\
(P=0.09) \\
3.16\end{array}$ \\
\hline Selenate III & $\mathrm{mM} / 100 \mathrm{ml}$ & $\begin{array}{c}3.3 \pm 0.2 \\
(P=0.02) \\
\left(P_{\mathrm{Sc}}=0.005\right)^{\mathrm{c}} \\
3.8\end{array}$ & $\begin{array}{c}0.94 \\
(P=0.30) \\
\left(P_{\mathrm{Sc}}=0.009\right) \\
17.9\end{array}$ & $\begin{array}{c}0.16 \pm 0.03 \\
(P=0.30) \\
\left(P_{\mathrm{Sc}}=0.142\right) \\
2.99\end{array}$ & $\begin{array}{c}0.54 \pm 0.06 \\
(P=0.06) \\
\left(P_{\mathrm{Sc}}=0.008\right) \\
10.3\end{array}$ & $\begin{array}{c}0.20 \pm 0.05 \\
(P=0.34) \\
\left(P_{\mathrm{Sc}}=0.141\right) \\
3.77\end{array}$ & $\begin{array}{c}0.063 \pm 0.010 \\
(P=0.28) \\
\left(P_{\mathrm{sc}}=0.023\right) \\
1.19\end{array}$ & $\begin{array}{c}5.3 \pm 0.4 \\
(P=0.27) \\
\left(P_{\mathrm{Se}}=0.005\right) \\
100\end{array}$ & $\begin{array}{c}3.6 \pm 0.4 \\
(P=0.76) \\
\left(P_{\mathrm{Sc}}=0.048\right) \\
3.56\end{array}$ \\
\hline
\end{tabular}

${ }^{\mathrm{a}}$ the content $(\mathrm{mM})$ of the assayed VFAs in $100 \mathrm{ml}$ of the ruminal fluid; ${ }^{\mathrm{b}}$ in parentheses - statistical analyses of results; $P$-values: statistical analyses were carried out between the control group and the experimental groups ( ${ }^{\mathrm{SeY}} \mathrm{II}$ or $\left.{ }^{\text {Selenate }} \mathrm{III}\right)$; ${ }^{\mathrm{c}} P_{\mathrm{Se}}-P$-values: statistical analyses were carried out between ${ }^{\mathrm{SeY}} \mathrm{II}$ group and ${ }^{\text {Selenate }} \mathrm{III}$ group

The SeY diet tended to decrease $(\mathrm{P}<0.1)$ the AA/PA ratio in the ruminal fluid when compared with the control diet (Table 3). The selenate diet revealed negligible impact on the AA/PA ratio in the fluid when compared with the control diet, whereas the selenate diet increased $(\mathrm{P}<0.05)$ the $\mathrm{AA} / \mathrm{PA}$ ratio in comparison with the SeY diet.

Table 4. The concentration ${ }^{\mathrm{a}}$ of $\mathrm{CO}_{2}$ and $\mathrm{CH}_{4}$ in the rumen and values of $\mathrm{CO}_{2}$ and $\mathrm{CH}_{4}$ indexes

\begin{tabular}{|c|c|c|c|c|}
\hline \multirow{3}{*}{ Group } & \multicolumn{4}{|c|}{ Contents of fermentation products in the rumen } \\
\hline & $\mathrm{CO}_{2}$ & $\mathrm{CH}_{4}$ & \multirow{2}{*}{$\begin{array}{c}\mathrm{CO}_{2} \text { index } \\
\left({ }^{\text {index }} \mathrm{CO}_{2}\right)\end{array}$} & \multirow{2}{*}{$\begin{array}{c}\mathrm{CH}_{4} \text { index }^{\mathrm{b}} \\
\left.{ }^{\text {index }} \mathrm{CH}_{4}\right)\end{array}$} \\
\hline & \multicolumn{2}{|c|}{$\mathrm{mM} / 100 \mathrm{ml}$} & & \\
\hline Control & $2.59 \pm 0.47$ & $1.51 \pm 0.27$ & $0.31 \pm 0.03$ & $0.18 \pm 0.01$ \\
\hline${ }^{\mathrm{SeY}} \mathrm{II}$ & $\begin{array}{l}3.17 \pm 0.75 \\
(P=0.086)^{c}\end{array}$ & $\begin{array}{l}1.85 \pm 0.43 \\
(P=0.086)\end{array}$ & $\begin{array}{c}0.36 \pm 0.03 \\
(P=0.113)\end{array}$ & $\begin{array}{c}0.21 \pm 0.02 \\
(P=0.151)\end{array}$ \\
\hline Selenate III & $\begin{array}{c}2.16 \pm 0.24 \\
(P=0.064) \\
\left(P_{\mathrm{Se}}=0.008\right)^{\mathrm{d}}\end{array}$ & $\begin{array}{c}1.26 \pm 0.14 \\
(P=0.064) \\
\left(P_{\mathrm{Se}}=0.008\right)\end{array}$ & $\begin{array}{c}0.30 \pm 0.02 \\
(P=0.76) \\
\left(P_{\mathrm{Se}}=0.041\right)\end{array}$ & $\begin{array}{c}0.17 \pm 0.01 \\
(P=0.82) \\
\left(P_{\mathrm{Se}}=0.041\right)\end{array}$ \\
\hline
\end{tabular}

athe contents of $\mathrm{CO}_{2}\left(\mathrm{C}_{\mathrm{CO} 2}\right)$ and $\mathrm{CH}_{4}\left(\mathrm{C}_{\mathrm{CH} 4}\right)$ calculated from the contents acetic, propionic and butyric acids in the ruminal fluid [21]; ${ }^{\mathrm{b}} \mathrm{CO}_{2}$ and $\mathrm{CH}_{4}$ indexes were calculated as follows: ${ }^{\text {index }} \mathrm{CO}_{2}=\mathrm{C}_{\mathrm{CO} 2}{ }^{*} \mathrm{~m}_{\text {rumen }} \mathrm{m}_{\text {lamb }}$ and ${ }^{\text {index }} \mathrm{CH}_{4}=$ $\mathrm{C}_{\mathrm{CH} 4}{ }^{*} \mathrm{~m}_{\text {rumen }} / \mathrm{m}_{\text {lamb }}$, respectively; $\mathrm{m}_{\text {rumen }}$ - weight of a rumen content $(\mathrm{kg}) ; \mathrm{m}_{\text {lamb }}$ - weight of lambs $(\mathrm{kg}) ;{ }^{\mathrm{c}}$ in parentheses - statistical analyses of results; $P$-values: statistical analyses were carried out between the control group and the experimental groups ( ${ }^{\mathrm{SeY}} \mathrm{II}$ or $\left.{ }^{\text {Selenate }} \mathrm{III}\right) ;{ }^{\mathrm{d}} P_{\mathrm{Se}}-P$-values: statistical analyses were carried out between ${ }^{\text {SeY }} \mathrm{II}$ group and Selenate III group 
The selenate diet tended to decrease $(\mathrm{P}<0.1)$ the concentrations of $\mathrm{CH}_{4}$ and $\mathrm{CO}_{2}$ in the rumen when compared with the control diet (Table 4). In contrast, the SeY diet increased concentrations of $\mathrm{CH}_{4}$ and $\mathrm{CO}_{2}$ in the rumen in comparison with the control diet (a tendency; $\mathrm{P}<0.1)$ and the selenate $\operatorname{diet}(\mathrm{P}<0.01)$. Moreover, the SeY diet significantly increased $(\mathrm{P}<0.05)$ the indexes of $\mathrm{CO}_{2}$ and $\mathrm{CH}_{4}\left({ }^{\text {index }} \mathrm{CO}_{2}\right.$ and $\left.{ }^{\text {index }} \mathrm{CH}_{4}\right)$ in comparison with the selenate diet.

\section{Effects of experimental diets on FAs concentration in the ruminal fluid, mi- crobiota and muscles of lambs}

The SeY added to the diet increased the concentration sums of saturated fatty acids (SFAs) (tendency; P<0.1), Eodd-SFAs (P<0.05), $\Sigma$ CLA (tendency; $\mathrm{P}<0.1$ ), atherogenic-SFAs (A-SFA) (P<0.05), thrombogenic-SFAs (T-SFA) (tendency; $\mathrm{P}<0.1$ ), monounsaturated FAs ( $\Sigma$ MUFAs) (tendency; $\mathrm{P}<0.1)$ and $\Sigma$ PUFAs $(\mathrm{P}<0.05)$, including $\Sigma$ n-6PUFAs, $\Sigma$ n-3PUFAs and $\Sigma$ n-3LPUFAs, in the ruminal fluid when compared with the control diet (Table 5). The SeY and selenate diets increased $(\mathrm{P}<0.05$ or $\mathrm{P}<0.1)$ the concentration of trans11C18:1 (t11C18:1) and the concentration sums of all positional isomers of $c$ C18:1 $\left(\sum_{c} \mathrm{C} 18: 1\right)$ and $\mathrm{n}$-3PUFAs ( $\sum \mathrm{n}$-3PUFAs) in the ruminal fluid in comparison with the control diet. The selenate diet decreased $(\mathrm{P}<0.05)$ the index of the final biohydrogenation $(\mathrm{BH})$ of $t 11 \mathrm{C} 18: 1$ to $\mathrm{C} 18: 0\left({ }^{\mathrm{C} 18: 0} \mathrm{BH}_{\text {index }}\right)$ in the fluid when compared with the control and SeY diets. The SeY diet increased the concentrations of A-SFA $(\mathrm{P}<0.05)$ and T-SFA (tendency; $\mathrm{P}<0.1)$ in the fluid in comparison with the selenate diet.

Table 5. The concentrations $(\mu \mathrm{g} / \mathrm{g})$ of C18:0, t11C18:1, c9t11CLA, the sums of $\alpha 18: 1$, SFAs, odd-chain-SFAs, iso-SFAs, MUFAs, PUFAs, all FAs ( $2 F A s)$, atherogenic SFA (A-SFA), thrombogenic SFA (T-SFA), n-3PUFAs, n-6PUFAs, n-3 LPUFAs, the index of the final biohydrogenation to C18:0 and ratios of $\Sigma$ SFAs, $\Sigma$ PUFAs and $\Sigma$ n-3LPUFAs to $\Sigma$ PUFAs, $\Sigma$ UFAs or $\Sigma F A$ in the ruminal fluid

\begin{tabular}{|c|c|c|c|c|c|c|}
\hline \multirow{2}{*}{ Item } & \multicolumn{3}{|c|}{ Group } & \multicolumn{3}{|c|}{ Significance of effects $^{\circ}$} \\
\hline & Control & ${ }^{\mathrm{SeY}} \mathrm{II}$ & ${ }_{\text {Selenate }}$ III & C-SeY & $\mathrm{C}-\mathrm{SeO}_{4}$ & $\mathrm{SeY}-\mathrm{SeO}_{4}$ \\
\hline C18:0 & $455 \pm 131$ & $553 \pm 110$ & $466 \pm 110$ & 0.048 & 0.91 & 0.08 \\
\hline$\sum_{c} \mathrm{C} 18: 1^{a}$ & $107 \pm 35$ & $138 \pm 31$ & $144 \pm 28$ & 0.08 & 0.04 & 0.47 \\
\hline t11C18:1 & $5.1 \pm 2.4$ & $6.7 \pm 1.6$ & $6.6 \pm 1.6$ & 0.06 & 0.045 & 0.48 \\
\hline c9+11CLA & $19 \pm 7$ & $24 \pm 7$ & $22 \pm 8$ & 0.08 & 0.17 & 0.29 \\
\hline$\Sigma$ CLA $^{\mathrm{b}}$ & $21 \pm 7$ & $27 \pm 7$ & $24 \pm 8$ & 0.09 & 0.29 & 0.19 \\
\hline$\Sigma \mathrm{SFAs}^{\mathrm{c}}$ & $760 \pm 201$ & $920 \pm 141$ & $769 \pm 161$ & 0.09 & 0.47 & 0.09 \\
\hline$\sum o d d-S F A s{ }^{d}$ & $20 \pm 5$ & $26 \pm 3$ & $21 \pm 5$ & 0.046 & 0.35 & 0.06 \\
\hline$\sum i s o-S F A s{ }^{e}$ & $10 \pm 1$ & $13 \pm 2$ & $12 \pm 2$ & 0.41 & 0.42 & 0.47 \\
\hline$\Sigma$ MUFAs ${ }^{\mathrm{f}}$ & $145 \pm 43$ & $189 \pm 40$ & $185 \pm 39$ & 0.06 & 0.047 & 0.47 \\
\hline ¿PUFAs ${ }^{\mathrm{g}}$ & $52 \pm 10$ & $69 \pm 12$ & $61 \pm 14$ & 0.03 & 0.11 & 0.15 \\
\hline
\end{tabular}


cont. Table 5.

\begin{tabular}{|c|c|c|c|c|c|c|}
\hline$\Sigma$ FAs & $957 \pm 252$ & $1178 \pm 179$ & $1015 \pm 211$ & 0.048 & 0.17 & 0.09 \\
\hline $\mathrm{A}-\mathrm{SFA}^{\mathrm{h}}$ & $199 \pm 47$ & $248 \pm 29$ & $208 \pm 38$ & 0.04 & 0.41 & 0.03 \\
\hline T-SFA $^{\mathrm{i}}$ & $646 \pm 179$ & $791 \pm 136$ & $668 \pm 142$ & 0.09 & 0.41 & 0.09 \\
\hline${ }^{\mathrm{C} 18: 0} \mathrm{BH}_{\text {index }}{ }^{\mathrm{i}}$ & $0.989 \pm 0.002$ & $0.988 \pm 0.002$ & $0.986 \pm 0.004$ & 0.12 & 0.02 & 0.04 \\
\hline$\sum \mathrm{n}-3$ PUFAs ${ }^{k}$ & $12.2 \pm 2.3$ & $17.7 \pm 4.3$ & $15.9 \pm 4.7$ & 0.03 & 0.06 & 0.35 \\
\hline$\sum \mathrm{n}-6 \mathrm{PUFAs}{ }^{1}$ & $25.5 \pm 4.4$ & $32.8 \pm 6.4$ & $28.8 \pm 6.1$ & 0.02 & 0.24 & 0.24 \\
\hline$\sum \mathrm{n}-3 \mathrm{LPUFAs}{ }^{\mathrm{m}}$ & $7.5 \pm 2.0$ & $10.4 \pm 2.6$ & $8.8 \pm 3.0$ & 0.046 & 0.39 & 0.15 \\
\hline$\sum n-6 / \sum n-3^{n}$ & $2.09 \pm 0.38$ & $1.85 \pm 0.42$ & $1.81 \pm 0.34$ & 0.19 & 0.12 & 0.47 \\
\hline$\Sigma$ SFAs/ $\Sigma$ PUFAs & $12.5 \pm 1.7$ & $11.6 \pm 1.3$ & $11.0 \pm 1.1$ & 0.29 & 0.15 & 0.19 \\
\hline$\Sigma$ SFAs/ $\Sigma$ UFAs & $3.85 \pm 0.33$ & $3.57 \pm 0.52$ & $3.12 \pm 0.21$ & 0.24 & 0.004 & 0.06 \\
\hline$\Sigma \mathrm{SFAs} / \Sigma \mathrm{FAs}$ & $0.794 \pm 0.015$ & $0.781 \pm 0.026$ & $0.757 \pm 0.013$ & 0.24 & 0.004 & 0.08 \\
\hline$\Sigma$ PUFAs $/ \Sigma F A s$ & $0.055 \pm 0.007$ & $0.059 \pm 0.005$ & $0.060 \pm 0.006$ & 0.34 & 0.397 & 0.45 \\
\hline$\Sigma$ LPUFAs $/ \Sigma F A s$ & $0.0100 \pm 0.0017$ & $0.0101 \pm 0.0011$ & $0.0097 \pm 0.0014$ & 0.40 & 0.41 & 0.39 \\
\hline$\Sigma \mathrm{n}-3 \mathrm{LPUFAs} / \Sigma \mathrm{FAs}$ & $0.0078 \pm 0.0006$ & $0.0088 \pm 0.0012$ & $0.0087 \pm 0.0012$ & 0.08 & 0.41 & 0.45 \\
\hline
\end{tabular}

${ }^{a}$ the sum of positional isomers of $c \mathrm{C} 18: 1 ;{ }^{\mathrm{b}}$ the sum of $c, t / t, c \mathrm{CLA}, t+\mathrm{CLA}, c \mathrm{CLA}$ isomers; ${ }^{\mathrm{c}}$ the sum of C6:0, C8:0, C9:0, C10:0, C11:0, C12:0, C13:0, C14:0, C15:0, C16:0, C17:0, C18:0, C20:0, C21:0, C22:0, C23:0, C24:0; ${ }^{\mathrm{d}}$ the sum of $\mathrm{C} 15: 0$ and $\mathrm{C} 17: 0$; ${ }^{\mathrm{e}}$ the sum of iso-C14:0, iso-C15:0, iso-C16:0, iso-C17:0; ${ }^{\mathrm{f}}$ the sum of $\sum_{\downarrow} \mathrm{C} 14: 1, \sum_{\downarrow} \mathrm{C} 15: 1, \sum_{c} \mathrm{C} 16: 1$, $\Sigma_{c} \mathrm{C} 16: 1, \Sigma_{c} \mathrm{C} 17: 1, \sum_{t} \mathrm{C} 18: 1, \Sigma_{c} \mathrm{C} 18: 1, c 11 \mathrm{C} 20: 1, \Sigma_{c} \mathrm{C} 22: 1, c 15 \mathrm{C} 24: 1 ;{ }^{g}$ the sum of $c 912 \mathrm{C} 16: 2, c 6 c c 12 \mathrm{C} 16: 3$, CLA isomers, n-3PUFAs, n-6PUFAs; ${ }^{\mathrm{h}}$ the sum of C12:0, C14:0, C16:0; ${ }^{\mathrm{i}}$ the sum of C14:0, C16:0, C18:0; ${ }^{\mathrm{i}}$ the index of the final biohydrogenation to $\mathrm{C} 18: 0=\mathrm{C} 18: 0 /(\mathrm{C} 18: 0+\mathrm{t} 11 \mathrm{C} 18: 1) ;{ }^{k}$ the sum of $c 912 c 15 \mathrm{C} 18: 3, \mathrm{n}-3 \mathrm{LPUFAs} ;{ }^{1}$ the sum of $c 9 c 12 \mathrm{C} 18: 2, c 6 c 9 c 12 \mathrm{C} 18: 3, c 11 c 14 \mathrm{C} 20: 2, c 8 c 11 c 14 \mathrm{C} 20: 3, c 5 c 8 c 11 c 14 \mathrm{C} 20: 4, c 13 c 16 \mathrm{C} 22: 2, c 7 c 10 c 13 c 16 \mathrm{C} 22: 4{ }^{\mathrm{m}}$ the sum of $c 11 c 14 c 17 \mathrm{C} 20: 3, c 8 c 11 c 14 c 17 \mathrm{C} 20: 4, c 5 c 8 c 11 c 14 c 17 \mathrm{C} 20: 5, c 7 c 10 c 13 c 16 c 19 \mathrm{C} 22: 5, c 4 c 7 c 10 c 13 c 16 c 19 \mathrm{C} 22: 5$; ${ }^{\mathrm{n}}$ the ratio of n-6PUFAs to n-3PUFAs; ${ }^{\circ} \mathrm{C}-\mathrm{SeY}$ and $\mathrm{C}_{-} \mathrm{SeO}_{4}-\mathrm{P}$-values: statistical analyses were carried out between the control group and the experimental groups ( ${ }^{\mathrm{SeY}} \mathrm{II}$ or ${ }^{\text {Selenate }} \mathrm{III}$ ); $\mathrm{SeY}_{-} \mathrm{SeO}_{4}-P$-values: statistical analyses were carried out between SeY II group and Selenate III group

The SeY diet has been shown to reduce the concentration of $\mathrm{C} 18: 0(\mathrm{P}<0.1), \Sigma_{c} \mathrm{C} 18: 1$

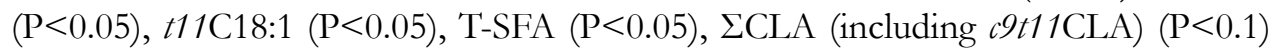
and $\Sigma$ PUFAs $(\mathrm{P}<0.1)$ (including $\Sigma \mathrm{n}-3 \mathrm{PUFAs}$ and $\Sigma \mathrm{n}$-3LPUFAs) in microbiota in comparison with the control diet (Table 6). In contrast, the selenate diet more efficiently increased the concentration of C18:0 ( $<<0.05), \Sigma_{c}$ C18:1 $(\mathrm{P}<0.1)$, 111C18:1 ( $\left.<<0.01\right)$, T-SFA $(\mathrm{P}<0.1)$ and ECLA $(\mathrm{P}<0.05)$, including 9 t11CLA $(\mathrm{P}<0.1)$, in microbiota than the SeY diet. The selenate diet tended to reduce the concentration of $\Sigma$ SFAs $(\mathrm{P}<0.1)$ and $\sum o d d$-SFAs $(\mathrm{P}<0.1)$ when compared with the control diet. The diet including selenate more efficiently decreased $(\mathrm{P}<0.05)$ the concentration of A-SFA, $\Sigma$ MUFAs and $\Sigma F A$ in microbiota than the control diet. The selenate diet more efficiently decreased $(\mathrm{P}<0.05)$ the concentration of $\Sigma \mathrm{n}$-3LPUFAs and the ratios of $\Sigma \mathrm{n}$-6PUFAs to $\sum$ n-3PUFAs $\left(\sum n-6 / \sum n-3\right)$ and $\Sigma$ SFAs to $\Sigma$ PUFAs ( $\Sigma$ SFAs $/ \Sigma$ PUFAs) in microbiota than the SeY diet.

In the current study we investigated the effects of SeY and selenate added to the diet on concentrations of $\Sigma$ SFAs, $\Sigma o d d$-SFAs, $\Sigma$ iso-SFAs, all UFAs ( $\Sigma$ UFAs) and $\Sigma F$ As in $M L D$ and $M B F$ of lambs (Table 7). The selenate diet revealed a negligible impact 
on the concentrations of $\Sigma$ SFAs, $\Sigma$ UFAs and $\Sigma F A$ s in $M L D$ and $M B F$ of lamb in comparison with the control diet. In contrast, the SeY diet most efficiently increased the concentrations of $\Sigma$ SFAs $(\mathrm{P}<0.05)$, $\Sigma$ UFAs $(\mathrm{P}<0.05), \Sigma F A s(\mathrm{P}<0.05)$ and $\Sigma$ isoSFAs (tendency; $\mathrm{P}<0.1$ ) in $M B F$ of lambs. This diet usually insignificantly increased the concentration of $\Sigma$ SFAs $(\mathrm{P}<0.05), \Sigma$ UFAs $(\mathrm{P}>0.1)$ and $\Sigma F A s(\mathrm{P}>0.1)$ in $M L D$ in comparison with the control diet. In contrast, the selenate diet usually significantly reduced the concentration of $\Sigma$ SFAs $(\mathrm{P}<0.05)$, $\Sigma$ UFAs, $\Sigma F A s(\mathrm{P}<0.05)$ in $M L D$ and $M B F$ in comparison with the $\mathrm{SeY}$ diet. $\mathrm{SeY}(\mathrm{P}>0.1)$ or especially selenate $(\mathrm{P}>0.1)$ added to the diet insignificantly reduced the concentration of $\sum$ odd-SFAs in MLD compared with the control diet. The SeY and selenate diets significantly $(\mathrm{P} \leq 0.01)$ reduced the concentration of $\sum i s o$-SFAs in MLD when compared with the control diet.

Table 6. The concentrations of selected fatty acids and the values of ${ }^{\mathrm{C} 18: 0} \mathrm{BH}_{\text {index }}$, the ratios of $\Sigma$ SFAs, $\Sigma$ PUFAs and $\Sigma$ n-3 LPUFAs to $\Sigma$ PUFAs, $\Sigma$ UFAs or $\Sigma F A$ in the ruminal microbiota ${ }^{a}$

\begin{tabular}{|c|c|c|c|c|c|c|}
\hline \multirow{2}{*}{ Item } & \multicolumn{3}{|c|}{ Group } & \multicolumn{3}{|c|}{ Significance of effects } \\
\hline & Control & ${ }^{\mathrm{SeY}} \mathrm{II}$ & Selenate III & C-SeY & $\mathrm{C}-\mathrm{SeO}_{4}$ & $\mathrm{SeY}_{-\mathrm{SeO}_{4}}$ \\
\hline C18:0, $\quad \mathrm{mg} / \mathrm{g}$ & $12.2 \pm 5.8$ & $8.2 \pm 3.6$ & $11.5 \pm 3.3$ & 0.08 & 0.41 & 0.04 \\
\hline$\Sigma_{d} \mathrm{C} 18: 1, \quad \mathrm{mg} / \mathrm{g}$ & $2.07 \pm 0.76$ & $1.27 \pm 0.36$ & $1.74 \pm 0.48$ & 0.02 & 0.12 & 0.06 \\
\hline t11C18:1, $\mu \mathrm{g} / \mathrm{g}$ & $120 \pm 59$ & $47 \pm 38$ & $144 \pm 62$ & 0.03 & 0.34 & 0.005 \\
\hline `t11CLA, $\mu \mathrm{g} / \mathrm{g}$ & $409 \pm 207$ & $253 \pm 125$ & $480 \pm 275$ & 0.08 & 0.40 & 0.06 \\
\hline$\Sigma C L A, \quad \mu g / g$ & $414 \pm 212$ & $253 \pm 125$ & $489 \pm 275$ & 0.09 & 0.41 & 0.049 \\
\hline ¿SFAs, $\quad \mathrm{mg} / \mathrm{g}$ & $21.5 \pm 5.9$ & $19.7 \pm 3.9$ & $18.6 \pm 3.4$ & 0.29 & 0.08 & 0.34 \\
\hline ¿odd-SFAs, mg/g & $1.02 \pm 0.30$ & $0.87 \pm 0.26$ & $0.77 \pm 0.22$ & 0.19 & 0.09 & 0.29 \\
\hline Niso-SFAs, $\mathrm{mg} / \mathrm{g}$ & $0.92 \pm 0.39$ & $0.69 \pm 0.41$ & $0.64 \pm 0.14$ & 0.27 & 0.12 & 0.47 \\
\hline$\Sigma$ MUFAs, $\mathrm{mg} / \mathrm{g}$ & $5.6 \pm 1.7$ & $4.5 \pm 1.6$ & $4.2 \pm 0.8$ & 0.15 & 0.04 & 0.40 \\
\hline ¿PUFAs, $\mathrm{mg} / \mathrm{g}$ & $1.21 \pm 0.35$ & $0.93 \pm 0.25$ & $1.18 \pm 0.34$ & 0.09 & 0.34 & 0.16 \\
\hline$\Sigma F A s$ & $28.2 \pm 7.1$ & $25.0 \pm 4.3$ & $23.8 \pm 4.3$ & 0.09 & 0.045 & 0.15 \\
\hline A-SFA, $\quad \mathrm{mg} / \mathrm{g}$ & $7.6 \pm 2.0$ & $9.3 \pm 4.4$ & $5.7 \pm 0.5$ & 0.35 & 0.046 & 0.026 \\
\hline T-SFA, $\quad \mathrm{mg} / \mathrm{g}$ & $18.4 \pm 6.1$ & $14.3 \pm 3.2$ & $16.4 \pm 3.7$ & 0.04 & 0.24 & 0.09 \\
\hline$\sum \mathrm{n}-3$ PUFAs, $\mu \mathrm{g} / \mathrm{g}$ & $379 \pm 253$ & $248 \pm 168$ & $279 \pm 90$ & 0.08 & 0.15 & 0.15 \\
\hline$\Sigma \mathrm{n}-6$ PUFAs, $\mu \mathrm{g} / \mathrm{g}$ & $428 \pm 158$ & $427 \pm 165$ & $381 \pm 125$ & 0.20 & 0.14 & 0.23 \\
\hline$\Sigma \mathrm{n}-3 \mathrm{LPUFAs}, \mu \mathrm{g} / \mathrm{g}$ & $228 \pm 136$ & $164 \pm 81$ & $152 \pm 66$ & 0.07 & 0.18 & 0.048 \\
\hline$\sum n-6 / \sum n-3$ & $1.13 \pm 0.69$ & $1.72 \pm 0.78$ & $1.36 \pm 0.38$ & 0.02 & 0.24 & 0.02 \\
\hline$\Sigma$ SFAs/ $\Sigma$ PUFAs & $17.7 \pm 2.8$ & $20.9 \pm 5.9$ & $15.6 \pm 2.7$ & 0.20 & 0.20 & 0.047 \\
\hline$\Sigma$ SFAs/ $/$ UFAs & $3.16 \pm 0.81$ & $3.63 \pm 0.87$ & $3.42 \pm 0.52$ & 0.12 & 0.14 & 0.14 \\
\hline$\Sigma \mathrm{SFAs} / \Sigma \mathrm{FAs}$ & $0.757 \pm 0.046$ & $0.782 \pm 0.061$ & $0.774 \pm 0.029$ & 0.13 & 0.14 & 0.14 \\
\hline$\Sigma$ PUFAs $/ \Sigma F A s$ & $0.043 \pm 0.005$ & $0.037 \pm 0.011$ & $0.043 \pm 0.007$ & 0.20 & 0.046 & 0.03 \\
\hline$\Sigma$ LPUFAs $/ \Sigma F A s$ & $0.0095 \pm 0.0015$ & $0.0096 \pm 0.0017$ & $0.0078 \pm 0.0016$ & 0.12 & 0.14 & 0.14 \\
\hline$\Sigma \mathrm{n}-3 \mathrm{LPUFAs} / \Sigma \mathrm{FAs}$ & $0.0081 \pm 0.0036$ & $0.0066 \pm 0.0027$ & $0.0064 \pm 0.0015$ & 0.15 & 0.24 & 0.07 \\
\hline
\end{tabular}

a all abbreviations as in Table 5 


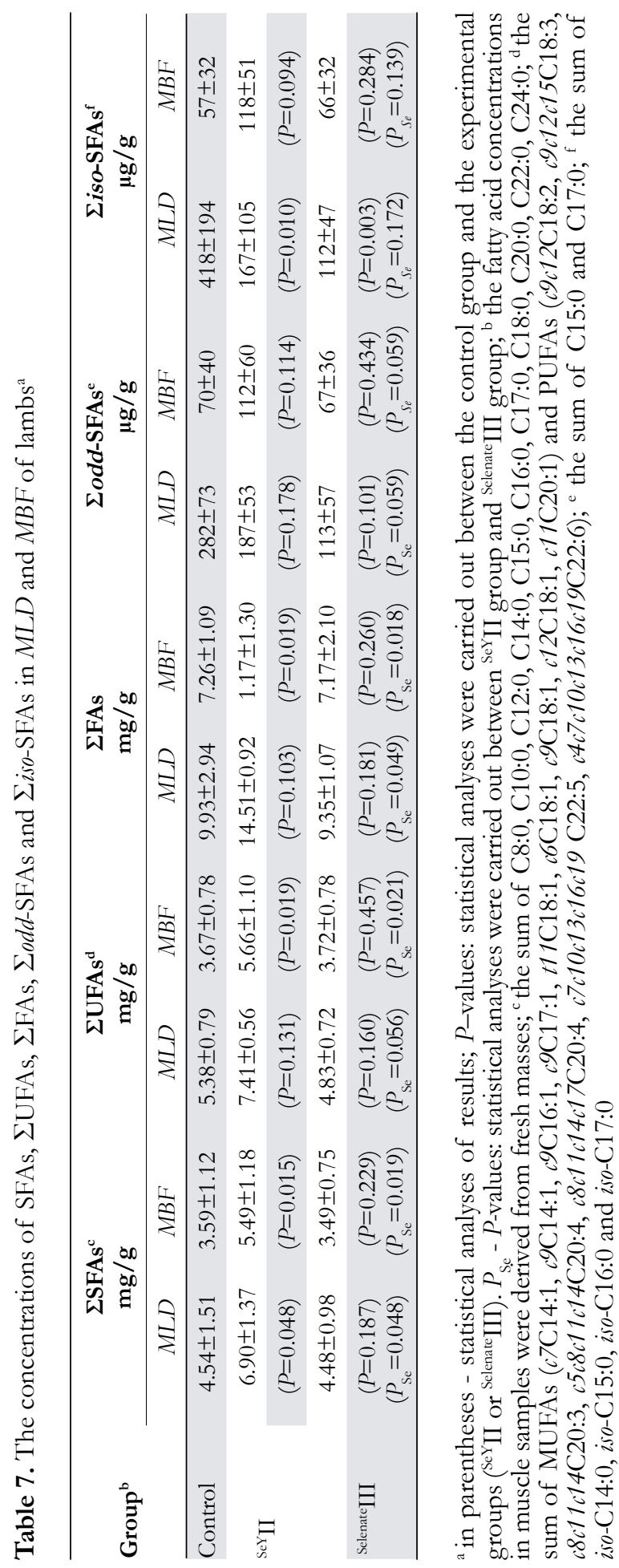




\section{DISCUSSION}

Our studies demonstrate that the chemical form of Se added to the diet including CA and FO affected the BMG of the examined lambs. No macroscopic lesions and toxic symptoms of the control and experimental diets were observed in lambs. Indeed, diets containing up to $2 \mathrm{mg}$ Se per $\mathrm{kg}$ would not be toxic for ruminants [22,23]. In contrast to selenate and especially selenite, Se-Met is less reactive, and because tRNA ${ }_{\text {Met }}$ does not discriminate between Se-Met and methionine (Met), dietary Se-Met is incorporated into body proteins in place of Met [24]. The fate of dietary Se-Met will depend upon whether Se released from Se-Met by ruminal degradation is further degraded to inorganic Se or re-incorporated into microbial proteins as Se-Cys or Se-Met [24].

\section{Effects of different chemical forms of Se on the VFAs profile in the ruminal fluid}

The primary end products of ruminal microbial digestion are VFAs. The changes in VFAs concentrations in the ruminal fluids might have been the result of an adjustment in the rumen due to the addition of different chemical forms of Se to the diet with $\mathrm{CA}$ and FO. These additives have a significant impact on the type or species of microorganisms in the rumen $[2,3,14,16,17,25,26]$. This was shown by the change in microbiota yield which affected VFAs abundance and fiber and protein digestion. Our results documented that the SeY diet decreased AA to PA ratio (AA/PA) in comparison with the control diet. Also, dietary SeY (rich in Se-Met) reduced fiber digestion when compared with the control and selenate diets. Our investigation indicated that the SeMet-proteins from dietary SeY most efficiently reduced fiber digestion and bacteria growth and most effectively increased microbial production of AA. In fact, AA is the major source of acetyl CoA for the synthesis of lipids in tissues; moreover, AA is oxidized throughout the most of animal body to generate ATP $[21,27,28]$.

The SeY diet most efficiently increased the production of $i$-BA, $i$-VA, 2-methylbutyric acid and straight-chain VFAs in the rumen. Ruminal $i$-BA, $i$-VA and 2-methylbutyric acid primarily originated from dietary proteins or recycling of microorganism proteins by ruminal oxidative deamination and decarboxylation of valine, leucine, and isoleucine, respectively [27]. In contrast, microbes utilize these iso-VFAs as a source of carbon skeleton to synthesize branched-chain amino acids [27]. Moreover, iso-VFAs can improve apparent dry matter digestibility and microbial growth, and stimulate microbial functions and enzyme activities in the rumen [28].

The selenate diet most efficiently decreased the concentrations of all straight-chain VFAs in the fluids. Considering the above, we argued that the selenate diet reduced the apparent intake of digestible energy and the intake of digestible organic matter. So, the SeY diet more efficiently increased microbial conversion of valine and leucine to $i$-BA and $i$-VA than the selenate diet. The selenate diet most effectively increased the BMG of lambs, whereas the SeY the diet revealed a negligible effect on the BMG 
when compared with the control diet (Table 2). The current studies and our previous investigations documented that dietary selenate most efficiently stimulated the accumulation of protein amino acids in the liver, heart, spleen, muscles or pancreas of lambs, whereas reduced the yield of FAs accumulation in the heart, spleen, pancreas and especially in muscles [29]. Thus, the amount of selenate added to the diet with FO and CA most effectively stimulated the micro-organism protein synthesis, while decreased the capacity of carbohydrate fermentation into VFAs and lipogenic enzymes in the lamb body. Our results indicated that the selenate diet most efficiently decreased the concentration of SVFAs and especially $\mathrm{CH}_{4}$ and $\mathrm{CO}_{2}$ in the rumen. The selenate diet improved growth performance of lambs, because this diet decreased the content of $\mathrm{CH}_{4}$ and $\mathrm{CO}_{2}$ as well as ${ }^{\text {index }} \mathrm{CH}_{4}$ and ${ }^{\text {index }} \mathrm{CO}_{2}$ in the rumen (Tables 2 and 4). Indeed, $\mathrm{CH}_{4}$ is the high-energy compound and its elimination, as a waste product, causes the loss of $\sim 8 \%$ of the total digestible energy of the diet [21]. In contrast, the SeY diet stimulated methanogenesis. So, this diet resulted in the decrease in the BMG of lambs when compared with the selenate diet.

\section{Effects of diets on the fatty acid profile in ruminal fluid and microbiota}

Our studies showed that the SeY and selenate diets affected the concentration of FAs, including CLA isomers, in the ruminal fluid and microbiota. It is apparent that the composition of FAs in the rumen has an impact on FAs profile in the muscles. Among all CLA isomers, 9711 CLA was the most abundant isomer in bacteria and protozoa; 9 9 11CLA proportions in protozoa were 8.6-times greater than in bacteria. Protozoa may have $\Delta 9$-desaturase activity that could convert $t 11 \mathrm{C} 18: 1$ to 9911 CLA [29]. In our study 9 t11CLA was the most abundant isomer ( $>98 \%$ ) in the microbiota (Table 6 ). The selenate diet most efficiently increased the content of $\Sigma$ CLA in microbiota, while the SeY diet most efficiently reduced this content. In contrast, the SeY diet more efficiently increased the content of $\Sigma$ CLA in the fluid than the selenate diet (Table 5). Thus, we argued that dietary SeY more efficiently stimulated the capacity of the bacterial isomerase involved in the formation of CLA isomers (mainly c 9 t11CLA) in the fluids than the selenate diet. However, enzymatically formed CLA isomers have higher bioavailability in microbiota cells of selenate-fed lambs than in microbiota cells of SeY-fed lambs (Table 6).

SeY or especially selenate added to the diet with $\mathrm{CA}$ and $\mathrm{FO}$ reduced the final $\mathrm{BH}$ in the fluid in comparison with the control diet (Table 5). Thus, our results are in agreement with previous studies in which Se-Met or selenate added to the ovine ruminal fluids enriched in PUFA decreased the final BH to C18:0 when compared with the control fluid $[25,26]$. So, the SeY and selenate diets affected the $\mathrm{BH}$ yield.

Our study showed that the contents of $\Sigma_{c}$ C18:1, t11C18:1, $\Sigma$ CLA (including

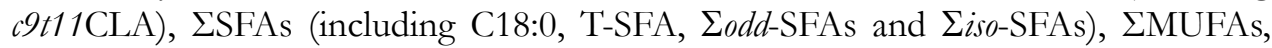
$\Sigma$ PUFAs (including $\sum \mathrm{n}$-3PUFA, $\Sigma \mathrm{n}$-6PUFA and $\sum \mathrm{n}$-3LPUFA) and $\Sigma F$ As were lower in the microbiota of lambs fed the SeY diet than lambs fed the control diet (Table 
6). In contrast, the contents of these fatty acids were higher in the fluid of lambs fed the SeY diet than in lambs fed the control diet. Therefore, we suggest that the SeY diet decreased the incorporation yield of these FAs (especially PUFAs, including CLA isomers and n-3LPUFAs) in microbiota compared with the control diet. Dietary SeY more effectively stimulated a defense mechanism against the accumulation of PUFAs in microbiota than the selenate treatment and especially the control diet.

The selenate diet stimulated the accumulation of $\Sigma_{c} \mathrm{C} 18: 1, t 11 \mathrm{C} 18: 1, \Sigma \mathrm{CLA}$ (including c9t11CLA) in microbiota in comparison with the SeY diet and especially the control diet (with the exception of $\Sigma \boldsymbol{C}$ C18:1). For this reason, we argue that dietary selenate (the very strong oxidant) reduced the $\mathrm{BH}$ (i.e. reduction of PUFAs to more saturated FAs). In fact, selenate contains the element selenium in the +6 oxidation state. In contrast, Se-Met, the main component of dietary SeY [19], contains the element selenium in the -2 oxidation state. Therefore, dietary SeY more effectively stimulated the $\mathrm{BH}$ in the ruminal fluid than dietary selenate (Table 5). Really, the selenate diet more effectively decreased ${ }^{\mathrm{C} 18: 0} \mathrm{BH}_{\text {index }}$ in the fluid than the SeY diet and the control. In fact, the SeY diet caused the reduction of the concentrations of $\mathrm{BH}$ intermediates (like $111 \mathrm{C} 18: 1$, 9t11CLA and other CLA isomers) in microbiota cells compared with the control and selenate diets (Table 6). Consequently, the selenate diet more efficiently reduced the content of C18:0 and $\Sigma$ SFAs/ $/$ PUFAs, $\Sigma$ SFAs/ $\Sigma$ UFAs and SSFAs/ $/ 2 F A s$ ratios in the fluid than the SeY diet (Table 5).

One of the microbial transformations in the rumen is the microbial synthesis of oddand branched-chain (iso and anteiso) FAs [30]. Odd-chain FAs (C15:0 and C17:0) are formed through elongation of propionate or valerate, while precursors of branchedchain $\mathrm{FAs}$ (isoC13:0, isoC14:0, isoC15:0, isoC16:0, isoC17:0, isoC18:0, anteisoC13:0, anteisoC15:0 and anteisoC17:0) are branched-chain amino acids (valine, leucine and iso-leucine) and their corresponding iso-VFAs ( $i$-BA, $i$-VA and 2-methyl butyric acid) $[30,31]$. Odd, iso and anteiso SFAs are important FAs within rumen microbial lipids to maintain optimal fluidity of the microbial cell membrane [31]. Iso, anteiso and odd SFAs can be used as biomarkers of cellulolytic or amylolytic bacteria. Higher proportions of iso-SFAs in solid associated bacteria were suggested to reflect their enrichment in cellulolytic bacteria, whereas amylolytic bacteria show low contents of branchedchain SFAs, especially iso-SFAs and are enriched in linear odd-SFAs and/or anteiso-SFAs $[30,31]$. Our study showed that the SeY or especially selenate added to the diet reduced the concentration sums of odd-SFAs and iso-SFAs in microbiota when compared with the control diet (Table 6). Interestingly, the SeY diet more efficiently stimulated the microbial synthesis of odd-SFAs and iso-SFAs in the fluid and microbiota than the selenate diet (Table 3). The SeY diet more efficiently increased the contents of precursors of $o d d$-SFAs and $i s o$-SFAs in the fluid (i.e., PA, VA, $i$-BA and $i$-VA) than the selenate diet. The selenate diet most efficiently reduced the contents of PA, VA and AA (used primarily by microorganisms for reproduction and growth).

\section{Effects of experimental diets on the fatty acid profiles in muscles}

The SeY and selenate diets resulted in the concentration changes of FAs in MLD and MBF (Table 7). The concentrations of $\Sigma$ SFAs, $\Sigma$ UFAs, $\Sigma F A$ s and $\Sigma o d d-S F A s$ and 
Eiso-SFAs were significantly impacted by the muscle type and the chemical form of dietary Se. The concentrations of these fatty acids in $M L D$ were considerably higher than in MBF. The SeY diet most effectively increased the content of $\sum$ iso-SFAs in $M B F$, while the control diet most efficiently increased the contents of $\sum o d d-S F A s$ and $\sum$ iso-SFAs in MLD. Similarly, the control diet most efficiently increased the contents of $\sum o d d$-SFAs and $\sum i s o$-SFAs in microbiota, while the selenate diet most effectively reduced the contents of these fatty acids in microbiota (Table 6). We argue that the content of $\sum o d d$-SFAs and $\sum i s o-S F A s$ in microbiota determine the accumulation yield of $\sum o d d$-SFAs and $\sum i s o$-SFAs in MLD. A similar good correlation was found between the contents of $\sum o d d$-SFAs and $\sum i s o-S F A s$ in microbiota and digest and $M B F$ of lambs fed the SeY and selenate diets. Indeed, Eodd-SFAs and $\sum i$ so-SFAs are largely derived from microbiota and they have been transferred to animal tissues. Thus, these FAs have been used as biomarkers of rumen fermentation [30,31].

The SeY diet most efficiently increased the content of SVFAs in the fluid (Table 3 ) and the contents of $\Sigma$ SFAs, $\Sigma$ UFAs and $\Sigma F A$ in $M L D$ and MBF. In contrast, the selenate diet most effectively reduced the content of SVFAs in the fluid and the contents of $\Sigma$ SFAs, $\Sigma F A$ s and $\Sigma o d d-S F A s$ in MLD and MBF. Indeed, SeY, rich in SeMet, is a stable and safe-storage mode for Se in the animal body. In contrast, selenate or selenite added to diets can stimulate the catalysis of hydrosulphide oxidation that results in the decrease in the biosynthesis yield of lipogenic enzymes (like acetyl-CoA carbo-xylase or FAs synthase) in animal tissues [24]. We suggest that the lowest content of AA in the fluid collected from lambs fed the selenate diet resulted in the decrease in the biosynthesis yield of acetyl CoA. AA is the major source of acetyl CoA for synthesis of lipids in lamb tissues. AA is oxidized throughout most of the animal body to generate ATP, while BA is oxidized in tissues for energy production. Therefore, the selenate diet most efficiently reduced the content of $\Sigma F A$ in $M L D$ and $M B F$, while the SeY diet most effectively increased the content of $\Sigma F A$ in $M L D$ and $M B F$.

\section{CONCLUSION}

Our studies constitute important information for nutritionists carrying out further studies to improve the nutritional quality of ruminant and human diets. The selenate diet improved the growth performance of lambs by reducing the concentrations of $\mathrm{CH}_{4}$ and $\mathrm{CO}_{2}$ in the rumen. The SeY diet and especially the selenate diet reduced the $\mathrm{BH}$ in the ruminal fluid in comparison with the control diet. The FAs profile was impacted by the muscle type and the chemical form of dietary Se. The selenate diet most efficiently decreased the concentration of $\Sigma$ VFAs in the fluids and the concentration of $\Sigma F A$ in $M L D$ and $M B F$, and most effectively increased the body mass (BM) and the body mass gain (BMG) of lambs. Thus, we suggest that the selenate diet decreased body fat $(\mathrm{BF})$, whereas considerably increased the lean body mass (LBM) of lambs $(\mathrm{LBM}=\mathrm{BM}-\mathrm{BF})$. Further investigations are needed to study the effects of dietary $\mathrm{CA}, \mathrm{FO}$ and different chemical forms of Se-compounds on the $\mathrm{BH}$, the level of $\mathrm{CA}$ metabolites and pro-healthy FAs in edible parts of lamb carcasses. 


\section{Acknowledgments}

This study was in part supported by the National Science Centre (NCN): Grant No. 2013/09/B/NZ9/00291 and by the statutory funds from the Kielanowski Institute of Animal Physiology and Nutrition, PAS, Jabłonna, Poland (Project No. II.1; 2015).

\section{Authors' contributions}

RM carried out chromatographic determination of volatile fatty acids in the ruminal fluids and performed the statistical analysis. ARW carried out chromatographic determination of fatty acids in muscles of lambs and performed the statistical analysis. EW prepared the diets for lambs and conducted experiments on lambs. MC conceived of the study, assisted with data analysis and manuscript drafting. All authors read and approved the final manuscript.

\section{Declaration of conflicting interests}

The author(s) declared no potential conflicts of interest with respect to the research, authorship, and/or publication of this article.

\section{REFERENCES}

1. Ortman K, Andersson R, Holst M: The influence of supplements of selenite, selenate, and yeast selenium on the selenium status of dairy heifers. Acta Vet Scand 1999, 40:23-34.

2. Ohgushi-Imamura T, Orden EA, Fujihara T: Utilization of microbial selenium collected from the rumen of sheep. J Anim Feed Sci 2014, 23:124-130.

3. Mainville AM, Odongo NE, Bettger WJ, McBride BW, Osborne VR: Selenium uptake by ruminal microorganisms from organic and inorganic sources in dairy cows. Can J Anim Sci 2009, 89:105-110.

4. Serra AB, Nakamura K, Matsui T, Harumoto T, Fujihara T: Inorganic selenium for sheep II. Its influence on rumen bacterial yield, volatile fatty acid production and total tract digestion of timothy hay. Asian Australas J Anim Sci 1994, 7:91-96.

5. Kim J, Van Soest PJ, Combs Jr GF: Studies on the effects of selenium on rumen microbial fermentation in vitro. Biol Trace Elem Res 1997, 56:203-213.

6. Del Razo-Rodriguez OE, Ramirez-Bribiesca JE, Lopez-Arellano R, Revilla-Vazquez AL, Gonzalez-Munoz SS, Cobos-Peralta MA, Hernandez-Calva LM, McDowell LR: Effects of dietary level of selenium and grain on digestive metabolism in lambs. Czech J Anim Sci 2013, 58(6):253-261.

7. Lyons TP, Jacques KA: Science and Technology in the feed industry. In: Proceedings of Alltech's 17th Annual Symposium. Nottingham, United Kingdom: Nottingham University Press; 2001, 309-415.

8. Traulsen H, Steinbrenner H, Buchczyk DP, Klotz LO, Sies H: Selenoprotein P protects low-density lipoprotein against oxidation. Free Rad Res 2004, 38:123-128. 
9. Demirel G, Wachira AM, Sinclair LA, Wilkinson RG, Wood JD, Enser M: Effects of dietary n-3 polyunsaturated fatty acids, breed and dietary vitamin $E$ on the fatty acids of lamb muscle, liver and adipose tissue. Brit J Nutr 2004, 91:551-565.

10. Konečný R, Hasoňová L, Trávníček J, Samková E, Hladký J, Kř́žová Z: Effect of organic selenium and iodine supplementation on selenium and thyroid hormones status of lactating ewes and lambs. Acta Vet Beograd 2015, 65:477-487.

11. Jovanović BI, Veličković M, Milanović S, Valčić O, Gvozdić D, Vranješ-Đurić S: Supplemental selenium reduces the levels of biomarkers of oxidative and general stress in peripartum dairy cows. Acta Vet Beograd 2015, 65:191-201.

12. Juniper DT, Phipps RH, Ramos-Morales E, Bertin G: Effect of dietary supplementation with selenium-enriched yeast or sodium selenite on selenium tissue distribution and meat quality in beef cattle. J Anim Sci 2008, 86:3100-3109.

13. Morán L, Giráldez FJ, Panseri S, Aldai N, Jordán MJ, Chiesa LM, Andrés S: Effect of dietary carnosic acid on the fatty acid profile and flavour stability of meat from fattening lambs. Food Chem 2013, 138:2407-2414.

14. Jordan MJ, Lax V, Rota MC, Loran S, Sotomayor JA: Effect of the phenological stage on the chemical composition, and antimicrobial and antioxidant properties of Rosmarinus officinalis L essential oil and its polyphenolic extract. Ind Crops Prod 2013, 48:144-152.

15. Wassowska I, Maia MRG, Niedźwiedzka KM, Czauderna M, Ribeiro JMCR, Devillard E, Shingfield KJ, Wallace RJ: Influence of fish oil on ruminal biohydrogenation of C18 unsaturated fatty acids. Brit J Nutr 2006, 95:1199-1211.

16. Buccioni A, Decandia M, Minieri S, Molle G, Cabiddu A: Lipid metabolizm in the rumen. New insights on the lipolysis and biohydrogenation with an emphasis on the role of endogenous plant factors. Anim Feed Sci Technol 2012, 174:1-25.

17. Wasowska I, Czauderna M, Kowalczyk J, Wallace RJ: Impact of selenite and selenate on conjugated linoleic acid isomers in incubated ruminal fluid. J Anim Feed Sci 2006, 15(Suppl. 1):97-100.

18. Meyer RM, Bartley EE, Deyoe CW, Colenbrander VF: Ration effects on rumen microbial protein synthesis and amino acid composition. J Dairy Sci 1967, 50:1327-1332.

19. Czauderna M, Kowalczyk J, Niedźwiedzka KM, Leng L, Cobanova K: Dietary selenized yeast and CLA isomer mixture affect fatty- and amino acid concentrations in the femoral muscles and liver of rats. J Anim Feed Sci 2009, 18:348-361.

20. Rozbicka-Wieczorek AJ, Więsyk E, Brzóska F, Śliwiński B, Kowalczyk J, Czauderna M: Efficiency of fatty acid accumulation into breast muscles of chickens fed diets with lycopene, fish oil and different chemical selenium forms. Afr J Biotechnol 2014, 13:16041613.

21. Wolin MJ: The Rumen fermentation: a model for microbial interactions in anaerobic ecosystems. Adv Microb Ecol 1979, 3:49-77.

22. McDowell LR, Davis PA, Cristaldi LA, Wilkinson NS, Buergelt CD, Van Alstyne R: Toxicity of selenium: fear or precaution? Feedstuffs 2005, 77:12-13.

23. Eun JS, Davis TZ, Vera JM, Miller DN, Panter KE, ZoBell DR: Addition of high concentration of inorganic selenium in orchardgrass (Dactylis glomerata L.) hay diet does not interfere with microbial fermentation in mixed ruminal microorganisms in continuous cultures. Prof Anim Sci 2013, 29:39-45.

24. Navarro-Alarcon M, Cabrera-Vique C: Selenium in food and the human body. Sci Total Envir 2008, 400:115-141. 
25. Czauderna M, Kowalczyk J, Marounek M: Selenite and selenate affect the fatty acid profile in in vitro incubated ovine ruminal fluid containing linseed oil. Czech J Anim Sci 2013, 58(7):328-341.

26. Czauderna M, Rozbicka-Wieczorek AJ, Wiesyk E, Krajewska-Bienias KA: Selenomethionine decreases biohydrogenation of C18-unsaturated fatty acids in ovine ruminal fluid incubated in vitro with $\alpha$-linolenic acid. Eur J Lipid Sci Technol 2015, 117:820-829.

27. Yang CMJ: Response of forage fiber degradation by ruminal microorganisms to branchedchain volatile fatty acids, amino acids, and dipeptides. J Dairy Sci 2014, 85:1183-1190.

28. Zhang HL, Chen Y, Xu XL, Yang YX: Effects of branched-chain amino acids on in vitro ruminal fermentation of wheat straw. Asian Australas J Anim Sci 2013, 26:523-528.

29. Niedźwiedzka MK, Kowalczyk J, Czauderna M: Influence of selenate and linseed oil on fatty-acid and amino-acid profiles in the liver, muscles, fat tissues and blood plasma of sheep. J Anim Feed Sci 2008, 17:328-343.

30. Or-Rashid MM, Odongo NE, McBride BW: Fatty acid composition of ruminal bacteria and protozoa, with emphasis on conjugated linoleic acid, vaccenic acid, and odd-chain and branched-chain fatty acids. J Animal Sci 2007, 85:1228-1234.

31. Fievez V, Colman E, Castro-Montoya JM, Stefanov I, Vlaeminck B: Milk odd- and branched-chain fatty acids as biomarkers of rumen function. Anim Feed Sci Technol 2012, 172:51- 65 .

\title{
UTICAJ RAZLIČITIH HEMIJSKIH OBLIKA SELENA DODATOG HRANI KOJA SADRŽI KARNOZINSKU KISELINU, RIBLJE ULJE I ULJE REPICE NA NASTANAK ISPARLJIVIH MASNIH KISELINA I METANA U BURAGU, KAO I PROFIL MASNIH KISELINA U SADRŽAJU BURAGA I MIŠIĆIMA JAGNJADI
}

\author{
MILTKO Renata, ROZBICKA-WIECZOREK J. Agnieszka, WIĘSYK Edyta, \\ CZAUDERNA Marian
}

Jagnjad su raspoređena u 3 grupe od po 6 životinja. Tokom 35 dana jagnjad je hranjena obrocima koji sadrže $2 \%$ ulje repice, $1 \%$ riblje ulje i $0,1 \%$ karnozinske kiseline (kontrolna grupa) ili dve ogledne suplementirane sa $0,35 \mathrm{mg} / \mathrm{kg}$ Se u obliku seleniziranog kvasca (SeY) ili selenata. Mišići Musculus longissimus dorsi (MLD) i Musculus biceps femoris $(\mathrm{MBF})$, tečnost iz buraga i mikroflora su uzeti od svake životinje. Dijetarna suplementacija sa SeY je efikasno stimulisala nakupljanje isparljivih lančanih masnih kiselina (VFAs), iso-razgrenatih lanaca VFAs, $\mathrm{CO}_{2} \mathrm{i} \mathrm{CH}_{4} \mathrm{u}$ ruminalnoj tečnosti. Obrok suplementiran selenitom je najefikasnije snižavao vrednosti $\mathrm{CO}_{2}, \mathrm{CH}_{4}$ i VFAs, uključujući linearne lance VFAs, sa izuzetkom iso-razgranatih lanaca VFAs. Kod kontrole u mikrobioti bio je najviši sadržaj iso-SFAs i neparnih zasićenih masnih kiselina. Dijetarna suplementacija sa SeY je u ruminalnoj tečnosti efikasno snizila odnos sirćetne kiseline prema propionskoj. Suplementacija selenatom je poboljšala performanse jagnjadi time što je u buragu snizila koncentraciju $\mathrm{CH}_{4}$ i $\mathrm{CO}_{2}$. 
Dodavanje selenita smanjilo je biohidrogenizaciju C 18:0 u poređenju sa kontrolom. Selenat je u poređenju sa SeY efikasnije snizio zbirnu koncentraciju svih SFA (SSFAs) i svih masnih kiselina (SFAs) u MLD i MBF. SeY je efikasnije uticao na porast koncentracija SFA (SSFAs) i masnih kiselina (SFAs) u MLD i MBF. Selenat je bio efikasan u povećanju telesne mase jagnjadi. 